\title{
発達性読み書き障害
}

\section{宇 野彰*}

\begin{abstract}
要旨：発達性読み書き障害（Developmental Dyslexia：DD）は，直訳すると発達性読み障害だが後天性の dyslexia とは異なり，読めなければ書けないので，発達性読み書き障害と翻訳されることが多い。DDは， (知能や) 年齢から推定される読み書きの習得度と乘離がある低さが認められ，環境要因では説明ができ ない障害である。すなわち, 診断評価としては, 知能検査, 読み書きの学習到達度, および文字習得にか かわる認知能力の 3 種類が必要となる。出現頻度は言語の種類によって影響され,「読み」に関しては文 字列から音韻列への変換の規則性が不規則な英語では出現頻度が高いと考えられる。すなわち, 同じ能力 であってもどの言語を用いるかによって, 読み書きに関する習得度が変化することになる。DD の生物学 的な原因としては，異所性灰白質や小脳回などが観察されていることから，細胞遊走の異常が仮説として は有力である。これら生物学的原因によって, 音韻, 視覚認知, 自動化, などの認知障害が生じ文字習得 に困難さを生じると考えられる。訓練法については, 日本語では症例シリーズ研究法により科学的根拠に
\end{abstract} もとづいた効果のある方法が 2 種報告されている。

(高次脳機能研究 36 (2)：170 176, 2016)

Key Words : 発達性読み書き障害, 根拠のある訓練方法, 定義, 出現頻度, 生物学的原因 developmental dyslexia, evidenced based practice, definition, prevalence, biological base

\section{I ． 発達性読み書き障害とは？}

発達性読み書き障害は Developmental Dyslexia の 日本語訳である。Dyslexia は直訳すると「読みの障 害」だが，先天性と考えられるこの障害は，読めな ければ書けないため多くの場合「発達性読み書き障 害」と翻訳される。この発達性読み書き障害は, 俳 優のトム・クルーズや映画監督のスピルバーグがそ うであることで有名であり，他にもバージンアトラ ンティック航空の社長やスウエーデン国王のカール 16 世グスタフなどもよく知られている。すなわち, 知能が正常であったとしても，通常の努力では文字 習得が困難な障害である。典型的な発達性読み書き 障害のある児童は, 音声言語は正常であるため一見 通常の児童とみられる。しかし，なぜか勉強ができ ないと思われていることが少なくない。就学前 11 月の時点では, 知能が十分に高くなくとも年長児は 約 $93 \%$ もらがなを読めているにもかかわらず（島 村ら 1994，2014に収集した宇野らの未発表デー 夕)、ひらがなを完璧に習得できていない小中学生 がいる。また，毎週の漢字テストでは合格できてい るのに, 一カ月前に覚えたはずの漢字が半分以上思 い出せないという児童生徒もいる。そして，音読は
可能だが，読むスピードが遅いために読解に時間が 必要な子どももいる。また，書いてしまえば文字の 形は整っていても，文字を想起することが困難な児 童生徒もいる。このような子どもたちは, 板書され た文字列をノートに写すことに時間がかかったり， 困難だったりする。文字列を写すためには音韻化し， そして文字列化することが必要であるため, 読み書 きに何らかの問題がある児童には大変不利な作業だ からである。そして彼らの多くは, 周囲から「急け ている」「努力不足」などと誤解されることが少な くない。しかし, 神経生物学的な原因に起因するこ の障害の出現頻度は, 障害種のなかでもっとも高い にもかかわらず，障害の内容についてあまり知られ ていない。発達性読み書き障害のある览童が, 家庭 や学校生活のなかで置かれている状況について動画 を作成したので，下記の URLを参考にされたい (URL : https://desolate-oasis-3776.herokuapp.com/ ユーザー名 : dyslexia パスワード : dFaPV7rt)。

\section{II . 用語と定義について}

「発達性読み書き障害」は診断名であるが, 単に「デ イスレクシア (Dyslexia)」と呼ぶ場合, 診断名なの か症状名（例： surface dyslexia や phonological dys- 
lexia な゙）なのか, どちらも使用する研究者がい るので, 論文や解説を読む際注意が必要である。ど ちらで使用しているのか意識していない研究者も少 なくないように思われる。そのような点で,「読字 障害」や「難読症」という用語は発達性の「読み」 の障害が「書字」障害を伴わず単独で出現するかの ような誤解を生むだけでなく, 診断名か症状名かも 曖昧な表現であるため, 使用する際には明確にする 必要があろう。また, 後天性の大脳損傷後に生じる 成人や小児のディスレクシアと区別するために,「発 達性」という表記を付記することがのぞましい。

国際 dyslexia 協会の発達性読み書き障害の定義の 翻訳を表 1 に, 日本の発達性ディスレクシア研究 会の定義を表 2 に示した。どちらも, 知能や年歯 相応の読み書き習得度と比べて乘離があり, 勉強を しないためなどといった環境要因では説明できな い, という共通点があると思われる。

\section{III. 出現頻度}

後天性の失読とは異なり発達性読み書き障害で は, 書字障害のみられない「読み」障害だけの症例 報告はほとんどない。「読み」障害の出現頻度は, 文字言語の構造, 特に文字列から音韻列への変換規 則の一貫性の違いによって変わることが報告されて いる。一般に, 英語圈のように文字列から音韻列へ の変換が不規則な（たとえば,「int」と表記された 文字列は hint, tint, mint など/int/ と読むことが多 いが,「pint」は/paint/と読むように一貫していない）
言語では出現頻度が高く, 文字列から音韻列への変 換が規則的なイタリア語, フィンランド語, スペイ ン語などでは出現頻度が低い，と考えられている。 さまざまなカットオフ值を用いるため, 出現頻度は 必ずしも一定ではないが，概して英語圈では $10 \%$ 以上と報告されている。一方, イタリア語やフィン ランド語では, 英語圈での約半分と低い出現頻度が 報告されている（Lindgrenら 1985, Lyytinenら 1995)。

日本語では，ひらがなで $0.2 \%$, カタカナで $1.4 \%$, 漢字で $6.9 \%$ と報告されている（Uno ら 2009）。文 字列から音韻列への变換が規則的なひらがな, カ夕 カナと不規則な漢字の影響と考えられ, 読み障害が 出現しやすい表記と出現しにくい表記と同一の言語 のなかでの対照的な出現頻度となっている。書字障 害の出現頻度はひらがな $1.6 \%$, カタカナ $3.8 \%$, 漢 字 $6.1 \%$ であった。ちなみに「読み」障害に関する 出現頻度は, 各言語において報告されているが, 「書 字」障害に関しては報告がほとんどなく, Unoら の報告のみと思われる。また, 変換が規則的な文字 言語では, 正答率や正答数などが指標となる正確性 よりも音読所要時間や音読潜時が指標となる流暢性 に焦点があてられることが少なくない。日本語の場 合, ひらがなの単語と非語, カタカナの単語と非語, 文章刺激を用いた調査では, $2.8 \%$ の児童が音読の 流暢性に問題を認めていた(未発表デー夕)。つまり， 40 人の通常学級に 3 人ぐらいは発達性読み書き障 害のある児童がいる計算になる。

表 1 国際dyslexia 協会の定義

Dyslexia は，神経生物学的原因に起因する特異的学習障害である。その特徵は，正確かつ（または）流暢な単語認識の困難 さであり，綴りや文字記号音声化の拙劣さである。こうした困難さは，典型的には，言語の音韻的要素の障害によるもの であり，しばしば他の認知能力からは予測できないものであり，また，通常の授業も効果的ではない。二次的には，結果 的に読解や読む機会が少なくなるという問題が生じ，それは語彙の発達や背景となる知識の増大を妨げるものとなり得る。

(Lyon, G. R., et al. : A definition of Dyslexia. Ann. Dyslexia, 53 : 1-14, 2003 より著者訳)

表 2 発達性ディスレクシア研究会の定義

発達性ディスレクシアは，神経生物学的に起因する障害である。その基本的特徵は，文字（列）の音韻化や音韻に対応す る文字 (列) の想起における正確性や流暢性の困難さである。こうした困難さは，音韻能力や視覚認知力などの障害によ り生じ，視覚や聴覚など感覚器の障害では生じない。また，年齢や全般的知能の水準からは予測できないことがある。環 境要因が直接の原因とはならない。 


\section{IV. 生物学的原因仮説と大脳機能低下部位 および灰白質の体積異常部位}

発達性読み書き障害が神経生物学的問題に起因す ることについては，世界中で異論はないと思われる が，どの遺伝子の問題であるのかについては，明確 になっていない。大脳に扔ける機能低下部位につい ては, 多くの報告があり, 日本語話者においても Katano ら (2009), 片野ら (2009), Kita ら (2013) などの報告があり, 結果は必ずしも一致していない。 ここでは，大脳の構造的な異常をVBM（Voxel Based Morphometry）を用いて, 機能的な異常を PET もしくは fMRI を用い, 双方が同様の結果を示 した報告について紹介する。Siokら（2008）は, 中国語での発達性読み書き障害例を対象にfMRI お よび，VBM を用いて双方において左前頭葉にある 中前頭回に問題があることを示した。しかし，その 後発達性読み書き障害と左中前頭回の関与について 明確に示した研究はなく，中国での発達性読み書き 障害の診断評価法も含めて今後の研究の進展が待た れる。一方, Paulesu ら（2001）はPETを用いてイ ギリス, イタリア, フランスの発達性読み書き障害 成人例を対象として, 活動が低かった部位が左側頭 葉と後頭葉であることを報告した。大部分が同じ対 象例に関して同じグループがVBM を用いて測定し たところ，類似の部位での灰白質の量や音韻処理に 関連する弓状束の接続に問題があることが示されて いる。このように, 構造と機能とのデータが一致し た研究であっても, 結果が異なっている状態は, 言 語の特徴の違いなのか, 手法の違いなのかについて は，まだ見解が一致していない。

しかし，fMRI やVBM を用いた報告では，成人に おいて大脳損傷によって失読や失書が生じるとされ る左大脳半球の側頭-後頭結合領域や側頭-頭頂結合 領域と類似している部位であるという報告が少なく ない。これらの部位の異常は, 細胞遊走 (migration) の異常などによって生じるとされる異所性灰白質 (ectopia) や小脳回（microgyri）による可能性があ る。なかでも ectopia は, 左大脳のシルヴィウス裂 周囲や側頭-後頭結合部周辺に観察されることが多 く, 文字習得に関係する認知能力の弱さとの関連が 指摘されている。Geschwind の弟子である Galaburda ら（1985）は，4名の発達性読み書き障害の ある人たちの脳に異所性灰白質があることを発見し
ている。

\section{V． 文字習得に関与する認知機能}

英語圈では広く，音韻認識が文字習得に大きくか かわることが知られてきた (Snowling 2000)。しか し, 音韻認識だけでは説明がつかない発達性読み書 き障害児群がいることから, 呼称スピードが遅い自 動化能力が低いことも「読み」障害にかかわると報 告されている（Wolfら 1999）。音韻障害 and/or 呼 称速度障害といういわゆる二重障害仮説である。一 方, 日本語ではひらがなの習得に関して, 天野(1986) をはじめとして音韻認識が重要であるという研究が あり,その後も引き続き音韻認識説が主流だったが, 他の認知能力を独立変数として比較していなかった という方法論上の大きな問題点があった。近年にお ける研究では, 音韻認識よりも自動化能力の重要性 が指摘され（猪俣ら 2016）, さらに視覚認知の関与 を示唆する報告もある（宇野ら 2007）。カタカナに 関連する認知機能についてはひらがなとほぼ同様の ようである。漢字の音読に関しては, 語彙や音韻認 識が, 漢字書字に関しては視覚認知の関与が報告さ れている (Unoら 2009)。

このように，文字表記が異なることにより，また 音読と書字というモダリティの違いにより，かかわる 認知機能やその貢献度が変化することから, 英語圈 で先行研究されていた結果が必ずしも日本語に当て はまらないことがわかってきている。それは，文字 言語の構造の違いが，音韻認識の貢献度に影響する という説 (Georgiou ら 2008, Papadopoulos 2001) や, 他言語での研究結果が英語圈の結果と異なるこ とにより, 徐々に英語圈の専門家の間で受け入れら れてきている段階と思われる。

\section{VI. 診断評価}

診断評価は，定義にもとづいて行われる。最初に 知能を調べる。英語圈においても日本語圈において も知能が正常である発達性読久書き障害児童と全般 的知能が十分ではない読み書きの問題がある児童と の間で，文字習得に関与する認知障害の種類や程度 に大きな差がないことが報告されている（Snowling 2000, 三盃ら 2016)。しかし, 臨床的には全般的知 能の程度によっては, トレーニングの効果や維持率 が異なるので事前に調べておく必要がある。

次に，読み書きに関する習得度を調べる。ここで 
の「読み」とは, 読解までの過程を含まない文字 (列) から音韻 (列) への変換のことであり, 音声変換さ れた場合には音読となる。この処理過程を decoding, 逆に音韻 (列) から文字（列）への変換課程 は encoding と呼ばれている。この decoding や encodingに関して，正確性と流暢性によって評価す る。正確性とは, 正答数や正答率などが指標となり, 流暢性は音読潜時や音読所要時間などによって評価 される。現在, 大学入試センター試験では, 読みの スピードが遅い受験生に 1.3 倍の試験時間の延長と いう支援を実施してすでに 6 年経過している。音読 （黙読においても音韻化）のスピードが遅いと読解 に時間がかかるからである。そして，国として，読 みのスピードが遅い受験生を支援しているというこ とは, 読みのスピードが遅いことは障害であること を示している。

最後に, 環境要因を排除するために, 文字習得に かかわる認知機能が弱いことを示す必要がある。日 本語の文字習得に必要な認知機能は, 基礎研究によ り, 音韻認識だけでなく, 視知覚や視覚記憶を含む 視覚認知や自動化能力および語彙が重要であること が判明している。したがって, 音韻検査, 視覚認知 検査, 自動化検査, 語彙検査が必要である。

\section{VII. 実際の検査}

失語症と同様, 客観的な検査が必須である。知能 検查は市販されているウェクスラー知能検查 (Wechsler Intelligence Scale for Children-Fourth Edition：WISC-IV) やレーヴン色彩マトリックス検 査 (Raven's Coloured Progressive Matrices : RCPM) を用いる。 RCPM は, WISC との相関が高いことか ら日本においても海外においても簡便な知能検査と して用いられている。各学年の基準值は, 宇野ら （2005）もしくは後述する「小学生の読み書きスク リーニング検査 (Screening Test of Reading and Writing for Japanese Primary School Children : STRAW)」(宇野ら 2006) に記載されている。

読み書きの学習到達度を調べる検査として, 漢字, カタカナ, ひらがな 3 種類の表記それぞれの正確性 について音読と書字を測定できる検査は, 現在のと ころ STRAW (2006) と「標準読み書きスクリーニン グ検查 (A Standardized Test for Assessing the Reading and Writing Ability of Japanese Children and Adolescents : STRAW-R)」(宇野ら 2016)のみと思われ
る。どちらも約 15 分で終了可能である。Kaufman Assesment Battery For Children Second Edition（K$\mathrm{ABC}$ II）にも, 音読と書字の項目があり 18 歳まで が対象であるが，3 種類の文字表記別には測定でき ない。一方, 流暢性の検査としては, 特異的発達障 害一臨床・評価のための実践ガイドライン（以後実 践ガイドライン版, 2010）がある。この検査は, 読 み書きに関連する検査のなかで唯一保険診療の対象 となっている検査である。しかし, 用いている刺激 はひらがな刺激だけであるためカタカナや漢字の障 害には対応が難しい点, 書字障害には対応していな い点, 基準值が高いという特徴がある（川崎ら 2013)。一方, STRAW-Rでは, ひらがな単語と非語, カタカナ単語と非語, 文章を刺激とした速読課題が 用いられている。対象者は小学 1 年生から高校 3 年 生まである。大学センター試験での試験時間の延長 を希望する受験生にも対応していることになる。

認知検査としては, 音韻認識検査としては, 単語 や非語の逆唱, 非語の復唱, 視知覚検査としては線 画同定課題, 視覚記憶検査として Rey-Osterrieth Complex Figure Test（ROCFT）, 自動化能力を測定 する検査としてはSTRAW-Rに含まれる RAN (Rapid Automatized Naming), 語彙力検査としては, 標準 抽象語理解力検査 (The Standardized Comprehension Test of Abstract Words : SCTAW) (春原ら 2002) や絵画語い理解力検査 (Picture Vocabulary TestRevised : PVT-R）（上野ら 2008）などの受容的語 彙力検査に加えて, 表出性語彙力検査としては, WISC での単語問題が使用可能である。

\section{VIII. 訓練の考え方と根拠にもとづく訓練方法}

失語症の訓練方法の一つにバイパス法という機能 再編成を想定する方法がある。同じ目標に対して, 障害されている機能を使わないようにし, 残されて いる機能を使って, カバーしていくという考え方に もとづいている。発達性読み書き障害に関してもこ の考え方に沿った訓練法が開発されている。さらに, 失語症の場合には単一症例での検討がほとんどであ るが, 症例シリーズ研究法を用いている分だけ信頼 性も高い。

粟屋ら（2012）は, 漢字書字に関して, 漢字を構 成している篇や旁などパーツを音声言語化する「聴 覚法」と, 通常の書いて覚える方法「視覚法」を 14 名を対象として比較し, 聴覚法のほうが, 習得 
度に関しても, 維持率に関しても視覚法よりも有意 に正答率が高いことを示した。聴覚法が有効だった 症例は, 知能が平均以上であり, 音声言語での記憶 カがAVLT (Auditory Verbal Learning Test) におい て高いことが示されており，かつ児童本人が練習方 法を変えることにより漢字を習得したいという意思 を明確に表明できた，という 3 条件を満たす児童で あった。

宇野ら（2015）も，上述の 3 条件を満たす览童 36 名を対象に, 症例シリーズ研究法を用いて検討 した結果，通常は 50 音表を記憶することができな い発達性読み書き障害群の子供たちは, 音声言語の 記憶力を活用した場合には 50 音表を覚えることが でき，その後の練習によって，書字の正確性だけで なく, 流暢性に関しても平均 40 日で正常域に達し たことを報告している。この方法では，ひらがなや カタカナ音読の正確性も有意に向上していた。漢字 では書字訓練を行っても必ずしも音読ができるよう になるわけではないが，かなでは書字訓練が音読力 に影響したことは，ひらがなやカタカナは文字列と 音韻列との対応が規則的であることと関係があると 思われる。

\section{IX．成人になった発達性読み書き障害例}

文字を習得する際，最初は一文字ずつ読んでいく が，ある時期から文字列をひとまとまりとして読む 単語全体処理をすることが知られている。Sambai ら（2012）は，典型発達児を対象に非語と単語を用 い, 音読潜時を分析した結果, 非語では文字列が長 くなると音読潜時は延長するが, 単語では小学 2 年 生以降は音読潜時が延長しても交互作用が認められ ないことを示した。小学 1 年と 2 年の間で大きな差 が認められたことから，音読ストラテジーが一文字 ずつの読み方から単語全体処理をする方向へ変化し たと考えられる。一方, 発達性読み書き障害児では, 単語でも非語でも同様に文字数が長くなれば音読潜 時が延長することから，一文字ずつの読み方をして いると考えられ，発達性読み書き障害のある成人に おいても同様の結果であった。このように，読みの 特徴は成人になっても大きくは変化せず, 結果的に 読みのスピードは遅い状態である。

このような発達性読み書き障害のある成人を対象 に, 半構造化面接を実施した結果, 自分が発達性読 み書き障害であることを職場で告知している人は一
人もいなかった。また, 調査当時には, 学習障害と して精神障害手帳を取得している人もいなかった。 基本的には，周囲の人たちに，理解されないであろ う, という諦めや誤解を恐れる気持ちからの行動の ようであった。以上の結果は, 社会的にも, そして 高次脳機能障害の専門家からの理解についても広く 必要とされているように思われるのである。

\section{文献}

1) 天野 清: 览童のかな文字の習得過程. 秋山書店, 東京, 1986.

2) 粟屋徳子, 春原則子, 宇野 彰, ほか：発達性読み書き 障害児における聴覚法を用いた漢字書字訓練方法の適用 について. 高次脳機能研究, 32：294-301,2012.

3 ) Galaburda, A. M., Sherman, G. F., Rosen, G. D., et al. : Developmental dyslexia : four consecutive patients with cortical anomalies. Ann. Neurol., 18 : 222-233, 1985.

4 ) 春原則子, 金子真人: 標準抽象語理解力検査 (SCTAW) (宇 野 彰, 監). インテルナ出版, 東京, 2002 .

5 ) Georgiou, K. G., Parrila, R. \& Papadopoulos, T. C. : Predictors of word decoding and reading fluencyacross languages varying in orthographic consistency. Journal of Educational Psychology, $100: 566-580,2008$.

6 ）発達性ディスレクシア研究会：発達性ディスレクシアの 定義（http://square.umin.ac.jp/dyslexia/factsheet.html).

7 ) 猪俣朋恵, 宇野 彰, 酒井 厚, ほか：年長児のひらが なの読み書き習得に関わる認知能力と家庭での読み書き 関連活動。音声言語医学, 57：208-216, 2016.

8 ) Katano, S., Moriguchi, Y., Ohnishi, T., et al. : Cortical activation of Japanese developmental dyslexic/dysgraphic adults and children during a working memory task with novel Chinese characters/non-verbal figures. Dyslexia Review, $20: 29-34,2009$

9 ）片野晶子, 宇野 彰, 守口善也, ほか：発達性 dyslexia 例における擬漢字を用いた作業記憶遂行中の大脳賦活部 位に関する研究. 音声言語医学, $50 ： 190-197,2009$.

10）川崎聡大, 石野絵美子 : 発達障害との真の共生に向けて 一発達障害を取りまく社会環境の変遷一, 社会的弱者と の真の共生を目指して一医療・福祉・教育の連携と提言 一 ( 天田城介, 川崎聡大, 伊藤智樹, 編). 富山大学東 アジア共成学創成の学際的融合研究, 富山, 2013, pp. 114-149.

11) Kita, Y., Yamamoto, H.,Oba, K., et al. : Altered brain activity for phonological manipulation in dyslexic Japanese children. Brain, $136: 3696-3708,2013$.

12) Lindgren, S. D., De Renzi, E. \& Richman, L. C. : Cross national comparison of developmental dyslexia in Italy and the United States. Child Dev., $56: 1404-1417,1985$.

13) Lyon, G. R., Shaywitz, S. E. \& Shaywitz, B. A. : A definition of Dyslexia. Ann. Dyslexia, $53: 1-14,2003$.

14) Lyytinen, H., Leinonen, S., Nikula, M., et al. : In search of 
the core features of dyslexia : observations concerning dyslexia in the highly orthographically regular Finnish language. In The varieties of orthographic knowledge II : relationships to phonology, reading, and writing (ed Berninger, V. W.). Kluwer Academic Publishers, Dordrecht, The Netherlands, 1995, pp. 177-204, 1-14.

15) Papadopoulos, T. C. : Phonological and cognitive correlates of word-reading acquisition under two different instructional approaches in Greek. European Journal of Psychology of Education, $16: 549-568,2001$.

16) Paulesu, E., Démonet, J. F., Fazio, F., et al. : Dyslexia : cultural diversity and biological unity. Science, $16: 2165^{-}$ 2167, 2001.

17）三盃亜美, 宇野 彰, 春原則子, ほか：全般的な知的水 準が境界領域であった読み書き障害群の認知能力. LD 研究, 25:2016 (in press).

18) Sambai, A., Uno, A., Kurokawa, S., et al. : An Investigation into Kana Reading Development in Normal and Dyslexic Japanese Children using Length and Lexicality Effects. Brain \& Development, 34 : 520-528, 2012.

19）島村直己, 三上廣子 : 幼巟のひらがなの習得一国立国語 研究所の 1967 年の調査との比較を通して一. 教育心理 学研究, 42: 70-76, 1994.

20) Siok, W. T., Niu, Z., Jin, Z., et al. : A structural-functional bases for dyslexia in the cortex of Chinese readers. Proceeding of the National Academy of Sciences of the United States of America, 105 : 5561-5566, 2008.

21) Snowling, M. J. : Dyslexia. Blackwell, Oxford UK, 2000.

22）特異的発達障害の臨床診断と治療指針作成に関する研究 チーム：特異的発達障害診断・治療のための実践ガイド
ライン一わかりやすい診断手順と支援の実際—（稲垣真 澄, 編)。診断と治療社, 東京, 2010 .

23）上野一彦, 名越斉子, 小貫 悟: PVT-R 絵画語い発達 検査. 日本文化科学社, 東京, 2008 .

24）宇野 彰, 春原則子, 金子真人, ほか：小学生の読み書 きスクリーニング検査(STRAW). インテルナ出版, 東京, 2006.

25）宇野 彰, 春原則子, 金子真人, ほか：標準読み書きス クリーニング検査 (STRAW-R). インテルナ出版, 東京, 2016.

26）宇野 彰, 春原則子, 金子真人, ほか：発達性 dyslexia の認知障害構造一音韻障害単独説で日本語話者の発達性 dyslexia を説明可能なのか?一. 音声言語医学, 48 : 105-111, 2007.

27）宇野 彰, 春原則子, 金子真人, ほか：発達性読み書き 障害児を対象としたバイパス法を用いた仮名訓練一障害 構造に即した訓練方法と効果および適応に関する症例シ リーズ研究—. 音声言語医学, 56 : 171-179, 2015.

28）宇野彰, 新家尚子, 春原則子, ほか：健常児における レーヴン色彩マトリックス検査一学習障害児や小児失語 症児のスクリーニングのために一. 音声言語医学, 46 : 185-189, 2005.

29) Uno, A., Wydell, T. N., Haruhara, N., et al. : Relationship between Reading/Writing Skills and Cognitive Abilities among Japanese Primary-School Children : Normal Readers versus Poor Readers (dyslexics). Reading and Writing, $22:$ 755-789, 2009.

30) Wolf, M. \& Bowers, P. G. : The double-deficit hypothesis for the developmental dyslexias. Journal of Educational Psychology, 91 : 415-438, 1999. 
Abstract

\title{
Developmental dyslexia
}

\begin{abstract}
Akira Uno*
'Developmental Dyslexia' is translated in Japanese as developmental reading and spelling disorder, because children with developmental dyslexia are showing both reading and spelling difficulties. Developmental dyslexia is not interpreted by environmental factors but cognitive factors and show discrepancy reading/ spelling attainment level from expected that from age and/or intellectual level. Namely, it is needed to conduct three kinds of tests for diagnosis ; general intelligence, attainment level of reading/spelling, cognitive abilities relating with reading/spelling acquisition. The prevalence of DD is thought to be affected by the writing system whether transparent (regular orthography) or opaque (irregular orthography). The prevalence of English as opaque writing system manifested higher than that of transparent one. It is possible that children show difficulties in one written language and not in other language. As ectopia and microgyri are observed in the adults with DD, migration disorder is one of the crucial hypothesis as the biological bases for DD. Biological bases underlying DD may produce cognitive disorders, such as phonological awareness, visual cognition, and automatization disorders. Two kinds of training method based on the scientific evidence reported using case series study design method in Japanese children with DD.
\end{abstract}

